\title{
JOURNAL.RU
}

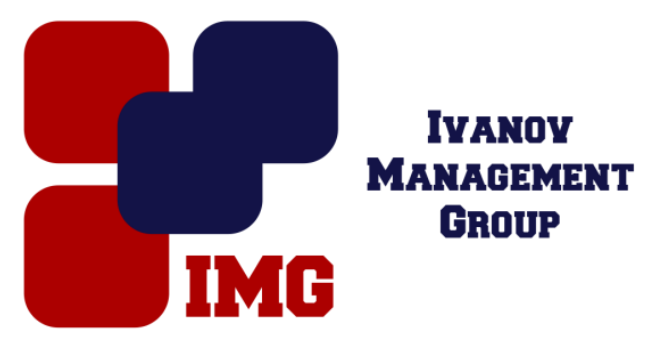

Кутяшова И.А. Чувашский государственный университет имени И.Н. Ульянова Чебоксары, Россия

doi: 10.18411/1j-30-06-2017-21

idsp 000001:1j-30-06-2017-21

\section{Об эффективности предпринимательской деятельности}

\section{Аннотация}

В статье рассматриваются подходы к определению понятия предпринимательской деятельности. Показана важность системы контроля при оценке эффективности предпринимательской деятельности.

Ключевые слова: предпринимательство, предпринимательская деятельность, эффективность предпринимательской деятельности, система контроля.

В настоящее время в условиях современной рыночной экономики отдельное место отводится предпринимательской деятельности. Поскольку всюду, где имели место рыночные отношения и где результатирующим показателем функционирования предприятия являлось извлечение прибыли, существовала предпринимательская деятельность, то современная экономическая система России просто не может быть представлена без предпринимательства.

Термин «предпринимательство» имеет английские корни, и его создателем принято считать английского учёного начала XVIII века Ричарда Кантильона, который характеризовал предпринимательство как экономическую деятельность, в результате которой приводятся в соответствие предложение и спрос на товары в условиях постоянного риска. Помимо Кантильона изучению термина «предпринимательская деятельность» посвятили свои труды многие другие выдающиеся ученые-экономисты, среди которых можно выделить Карла Маркса, Йозефа Шумпетера, Торстейна Веблена и т.д. Все они имели разные 
точки зрения и сравнивали предпринимательство с различными факторами производства.

2-ая статья ГК РФ описывает предпринимательскую деятельность так: «Предпринимательской является самостоятельная, осуществляемая на свой риск, деятельность, направленная на систематическое получение прибыли от пользования имуществом, продажи товаров, выполнения работ или оказания услуг лицами, зарегистрированными в этом качестве в установленном законом порядке».

Ключевой целью раз любого предприятия, вне зависимости от их масштаба, является повышение их эффективности. Под эффективностью понимается способность получить желаемые результаты с использованием минимального уровня издержек.

Эффективность деятельности предприятия находится под влиянием разнообразных факторы, и внешней, и внутренней среды. Внешним факторам делятся на технологические, экономические, правовые, природные и др. Под факторами внутренней среды понимаются внутренняя организация предприятия и развитость форм собственности. Для эффективной оценки предпринимательской деятельности была требуется применение показателей, охватывающих все элементы ее функционирования.

Можно выделить следующие показатели эффективности предпринимательской деятельности: объем продукции; инвестиционная и инновационная деятельность предприятия; валовой продукт; экспорт и импорт основной продукции.

Для проведения оценки деятельности предприятия требуется оценить показатели экономической эффективности. Именно благодаря им, складывается общее представление о степени конечного результата в соотношении с понеченными затратами или использованными ресурсами. Среди подобых показателей можно выделить общую рентабельность, рентабельность активов, уровень текущей ликвидности, уровень автономии, производительность труда, фондоотдачу, оборачиваемость оборотных средств, оборачиваемость кредиторской и дебиторской задолженности и другие. Именно после комплексной оценки данных показателей у руководства и управляющего персонала предприятия складывается объективная картина по поводу того, эффективно ли функционирует предприятие и не несёт ли оно убытки.

Для роста показателей эффективности деятельности предприятия необходимо использовать системы контроля. Они необходимы для оценки 
управления (реакция на изменения внешней среды) и выявления факторов, негативно влияющих на достижение запланированных результатов.

Предпринимательство - неотчуждаемая часть нынешего рыночного общества. Именно от его эффективной деятельности зависит плодотворная, приносящая успех работа предприятий и их конкурентоспособность на рынке. Следовательно, для улучшения деятельности предприятия нужно уметь правильно оценивать эффективность препринимательской деятельности, что можно достичь применяя определенные системы контроля.

\section{Литература}

1. Передков А. В. Генезис понятия «малое предпринимательство» // Актуальные инновационные исследования: наука и практика. - 2010. - № 4. - URL: http://actualresearch.ru/nn/2010_4/Article/economics/peredkov.htm.

2. «Гражданский кодекс Российской Федерации (часть первая)» от 30.11.1994 N 51-Ф3 (ред. от 07.02.2017). - URL: http://www.consultant.ru/document/cons_doc_LAW_5142/.

3. Асаул А. Н., Войнаренко М. П., Ерофеев П. Ю. Организация предпринимательской деятельности: учебник / Под ред. А. Н. Асаула. - СПб.: Гуманистика, 2004. - 448 с.

4. Ходырев В. А., Непомнящая Н. Г. Индивидуальный предприниматель в России: физическое или юридическое лицо // Инновации в науке. - 2014. - № 34. - С. 66-77. 